\title{
Chemical and Stress Resistances of Clostridium difficile Spores and Vegetative Cells
}

\author{
Adrianne N. Edwards, Samiha T. Karim, Ricardo A. Pascual, Lina M. Jowhar, \\ Sarah E. Anderson and Shonna M. McBride*
}

Emory Antibiotic Resistance Center, Department of Microbiology and Immunology, Emory University School of Medicine, Atlanta, GA, USA

\section{OPEN ACCESS}

Edited by: Neil Fairweather,

Imperial College London, UK

Reviewed by:

Wiep Klaas Smits,

Leiden University, Netherlands

Marcin Dembek

Newcastle University, UK

${ }^{*}$ Correspondence:

Shonna M. McBride

shonna.mcbride@emory.edu

Specialty section:

This article was submitted to Microbial Physiology and Metabolism,

a section of the journal

Frontiers in Microbiology

Received: 30 June 2016 Accepted: 12 October 2016

Published: 26 October 2016

Citation:

Edwards AN, Karim ST, Pascual RA,

Jowhar LM, Anderson SE and

McBride SM (2016) Chemical and Stress Resistances of Clostridium difficile Spores and Vegetative Cells.

Front. Microbiol. 7:1698

doi: 10.3389/fmicb.2016.01698
Clostridium difficile is a Gram-positive, sporogenic and anaerobic bacterium that causes a potentially fatal colitis. C. difficile enters the body as dormant spores that germinate in the colon to form vegetative cells that secrete toxins and cause the symptoms of infection. During transit through the intestine, some vegetative cells transform into spores, which are more resistant to killing by environmental insults than the vegetative cells. Understanding the inherent resistance properties of the vegetative and spore forms of $C$. difficile is imperative for the development of methods to target and destroy the bacterium. The objective of this study was to define the chemical and environmental resistance properties of $C$. difficile vegetative cells and spores. We examined vegetative cell and spore tolerances of three $C$. difficile strains, including $630 \Delta$ erm, a 012 ribotype and a derivative of a past epidemic strain; R20291, a 027 ribotype and current epidemic strain; and 5325, a clinical isolate that is a 078 ribotype. All isolates were tested for tolerance to ethanol, oxygen, hydrogen peroxide, butanol, chloroform, heat and sodium hypochlorite (household bleach). Our results indicate that $630 \Delta \mathrm{erm}$ vegetative cells (630 spo0A) are more resistant to oxidative stress than those of R20291 (R20291 spo0A) and 5325 (5325 spo0A). In addition, 5325 spoOA vegetative cells exhibited greater resistance to organic solvents. In contrast, $630 \Delta \mathrm{erm}$ spores were more sensitive than R20291 or 5325 spores to butanol. Spores from all three strains exhibited high levels of resistance to ethanol, hydrogen peroxide, chloroform and heat, although R20291 spores were more resistant to temperatures in the range of $60-75^{\circ} \mathrm{C}$. Finally, household bleach served as the only chemical reagent tested that consistently reduced $C$. difficile vegetative cells and spores of all tested strains. These findings establish conditions that result in vegetative cell and spore elimination and illustrate the resistance of C. difficile to common decontamination methods. These results further demonstrate that the vegetative cells and spores of various $C$. difficile strains have different resistance properties that may impact decontamination of surfaces and hands.

Keywords: Clostridium difficile, Clostridium difficile infection (CDI), anaerobe, spores, resistance, germination, sporulation 


\section{INTRODUCTION}

Clostridium difficile infection (CDI) is a serious, sometimes fatal, gastrointestinal (GI) disease that has emerged as a major healthcare concern in many hospitals, acute care and longterm care facilities (Rupnik et al., 2009; Dubberke and Olsen, 2012; CDC, 2013; Smits et al., 2016). Susceptibility to CDI can be induced by antibiotic treatment, which disrupts the native intestinal microbiota, creating a niche in which $C$. difficile thrives (Theriot and Young, 2015; Theriot et al., 2016). C. difficile spores enter the host by ingestion and germinate into vegetative cells when exposed to bile salts in the GI tract (Sorg and Sonenshein, 2008). C. difficile vegetative cells then produce multiple toxins that result in the characteristic diarrhea of CDI (Voth and Ballard, 2005; Shen, 2012; Janoir, 2016). As C. difficile vegetative cells transit through the host GI tract, a subset of the cells undergo sporulation, resulting in the formation of dormant spores that are shed in feces, along with vegetative cells (Koenigsknecht et al., 2015). Although CDI is a toxin-mediated disease, the ability for $C$. difficile to form spores is an important virulence factor because the spore serves as the infectious agent and facilitates efficient transmission from host-to-host (Deakin et al., 2012). The physical composition of the spore allows long-term persistence in the environment and confers resistance against desiccation, standard disinfectants and cleaning routines (Driks, 2002, 2003; Ali et al., 2011; Vohra and Poxton, 2011; Dubberke, 2012; Setlow, 2014).

The basic structure of $C$. difficile spores is similar to the spores of Bacillus subtilis and other related organisms, with the exception of the exosporium, the outermost layer of the C. difficile spore, which is absent in most spore formers (PizarroGuajardo et al., 2014, 2016a,b). The spore core, which contains the DNA and other cellular components, is layered by the inner and outer membranes, the cortex and the spore coat (reviewed in Paredes-Sabja et al., 2014). Many orthologs to key proteins that constitute the B. subtilis cortex and spore coat are not encoded in C. difficile (Henriques and Moran, 2007; Fimlaid et al., 2013), and the receptors and regulatory pathways that govern spore germination are not well conserved (Paredes et al., 2005; de Hoon et al., 2010; Francis et al., 2013; Bhattacharjee et al., 2016), further highlighting the differences between $C$. difficile spores and other bacterial spores. As the individual spore components provide resistance to different stresses (Russell, 1990), from survival in the environment to reactivation within the mammalian gut, elucidating the physical restraints of the $C$. difficile spore is paramount for understanding C. difficile biology and developing approaches for the eradication of $C$. difficile in clinical environments.

The purpose of this study was to characterize the resistance properties of the vegetative cells and spores of three $C$. difficile strains, including a derivative of a historical epidemic strain (630 $\Delta$ erm; 012 ribotype), a current epidemic strain (R20291; 027 ribotype) and a strain that is frequently found in animals and humans (5325; 078 ribotype). We observed that each strain has unique resistance properties that likely contribute to their ability to persist as circulating clinical isolates. Our results emphasize the importance of strain variation in C. difficile clinical isolates and provide additional evidence for stringent approaches to eradicate C. difficile spores and vegetative cells from surfaces.

\section{MATERIALS AND METHODS}

\section{Bacterial Strains and Growth Conditions}

The bacterial strains used in this study are described in Table $\mathbf{1 .}$ All $C$. difficile strains were routinely cultured in brain heart infusion-supplemented (BHIS) medium at $37^{\circ} \mathrm{C}$ in a Coy anaerobic chamber (Bouillaut et al., 2011; Edwards et al., 2013) unless otherwise indicated below.

\section{Construction of 5325 spo0A Mutant}

The pJS107-spo0A178TT plasmid containing the group II intron retargeted to the $s p o 0 A$ locus was conjugated into strain 5325 (ATCC BAA-1875, ribotype 078; Ho and Ellermeier, 2011; Fimlaid et al., 2013). Thiamphenicol-resistant colonies containing the pJS107-spo0A178TT plasmid were transferred to BHIS plates supplemented with $5 \mu \mathrm{g} \mathrm{ml}^{-1}$ erythromycin. Erythromycin-resistant colonies were isolated and screened for the $2 \mathrm{~kb}$ insertion in the spo0A locus using primers oMC444 and oMC1122.

\section{Vegetative Viability Assays}

To determine the susceptibility of vegetative cells to a variety of chemical and environmental conditions, the respective spo0A mutants of strains $630 \Delta \mathrm{erm}, \mathrm{R} 20291$ and 5325 were cultured overnight in BHIS medium. Cultures were grown to midexponential phase $\left(\mathrm{OD}_{600} \sim 0.5\right)$ and diluted 1:10 into fresh BHIS.

\begin{tabular}{|c|c|c|}
\hline $\begin{array}{l}\text { Plasmid or } \\
\text { Strain }\end{array}$ & $\begin{array}{l}\text { Relevant genotype } \\
\text { or features }\end{array}$ & $\begin{array}{l}\text { Source, } \\
\text { construction or } \\
\text { reference }\end{array}$ \\
\hline \multicolumn{3}{|l|}{ Strains } \\
\hline \multicolumn{3}{|l|}{ Escherichia coli } \\
\hline HB101 & $\begin{array}{l}\mathrm{F}^{-} \text {mcrB mrr hsdS2O }\left(\mathrm{r}_{\mathrm{B}}^{-} \mathrm{m}_{\mathrm{B}}^{-}\right) \\
\text {recA13 leuB6 ara-14 } \\
\text { proA2 lacY1 galk2 xyl-5 mtl-1 rpsL20 }\end{array}$ & B. Dupuy \\
\hline MC306 & HB101 pRK24 pJS107-spoOA178TT & Fimlaid et al., 2013 \\
\hline \multicolumn{3}{|l|}{ Clostridium difficile } \\
\hline 5325 & BAA-1875; ribotype 078 & ATCC \\
\hline $630 \Delta \mathrm{erm}$ & $\begin{array}{l}\text { Erm }{ }^{\mathrm{S}} \text { derivative of strain 630; } \\
\text { ribotype } 012\end{array}$ & $\begin{array}{l}\text { N. Minton; Hussain } \\
\text { et al., } 2005\end{array}$ \\
\hline R20291 & Clinical isolate; ribotype 027 & Stabler et al., 2009 \\
\hline $\begin{array}{l}\text { R20291 } \\
\text { spoOA }\end{array}$ & R20291 spoOA::erm & $\begin{array}{l}\text { Dawson et al., } \\
2012\end{array}$ \\
\hline $\begin{array}{l}\text { MC310 (630 } \\
\text { spoOA) }\end{array}$ & $630 \Delta$ erm spoOA::erm & $\begin{array}{l}\text { Edwards et al., } \\
2014\end{array}$ \\
\hline $\begin{array}{l}\text { MC724 (5325 } \\
\text { spoOA) }\end{array}$ & 5325 spo0A::erm & This study \\
\hline \multicolumn{3}{|l|}{ Plasmids } \\
\hline pRK24 & $\mathrm{Tra}^{+}, \mathrm{Mob}^{+} ; \mathrm{bla}$, tet & $\begin{array}{l}\text { Thomas and } \\
\text { Smith, } 1987\end{array}$ \\
\hline $\begin{array}{l}\text { pS107- } \\
\text { spo0A178TT }\end{array}$ & Group II intron targeted to spoOA & Fimlaid et al., 2013 \\
\hline
\end{tabular}


When the cultures reached an $\mathrm{OD}_{600} \sim 1.0$, cells were exposed to various concentrations of chemicals for $15 \mathrm{~min}$ as follows: (a) $1 \mathrm{ml}$ culture aliquots were mixed with 5-100 $\mu \mathrm{l}$ butanol (Fisher Scientific), chloroform (Acros Organics), hydrogen peroxide ( $3 \% \mathrm{H}_{2} \mathrm{O}_{2}$ as a commercially available aqueous solution) or sodium hypochlorite $(8.25 \% \mathrm{NaOCl}$ as commercially available concentrated household bleach) to achieve the indicated final concentrations, (b) $6 \mathrm{ml}$ culture aliquots were placed in $15 \mathrm{ml}$ screw-cap polypropylene conical tubes, cells were pelleted in a benchtop centrifuge at 4,000 rpm for $5 \mathrm{~min}$, suspended in equal volume pre-reduced $1 \mathrm{X}$ PBS, divided into $1 \mathrm{ml}$ aliquots and mixed with 5-100 $\mu \mathrm{l}$ concentration of $\mathrm{NaOCl}$ as indicated above, (c) $500 \mu \mathrm{l}$ of culture was combined with 100-300 $\mu \mathrm{l} 95 \%$ ethanol and brought to a final volume of $1 \mathrm{ml}$ with $\mathrm{dH}_{2} \mathrm{O}$, or (d) $1 \mathrm{ml}$ of culture was placed in $8 \mathrm{ml}$ glass screw-cap tubes and incubated at the indicated temperature in a heated water bath for $20 \mathrm{~min}$. $\mathrm{pH}$ was measured using a benchtop Accumet AB150 pH/MV meter. For exposure to oxygen, $2 \mathrm{ml}$ culture was placed in a sterile petri dish, removed from the anaerobic chamber, sealed with parafilm to reduce evaporation and aliquots were removed after $30 \mathrm{~min}, 1$, $3,6,9,12$, and $24 \mathrm{~h}$ incubation. After exposure, cells were serially diluted in either pre-reduced BHIS medium or 1X PBS and plated onto BHIS supplemented with $0.1 \%$ taurocholate. There was no difference in colony forming units (CFU) recovered from either diluent (data not shown). Untreated controls for each culture were diluted and plated to BHIS containing taurocholate prior to treatment to enumerate the initial CFU. Plates were enumerated after at least $24 \mathrm{~h}$ incubation at $37^{\circ} \mathrm{C}$.

\section{Preparation of Spores}

Isolated spores were prepared as previously described Edwards et al. (2013) with the following alterations. Briefly, overnight cultures of $C$. difficile strains grown in BHIS were diluted into fresh $\mathrm{BHIS}$ and grown to mid-exponential phase $\left(\mathrm{OD}_{600}\right.$ $\sim 0.5$ ). Two hundred microliter culture was spread onto 70:30 sporulation agar (Fimlaid et al., 2013) and incubated anaerobically at $37^{\circ} \mathrm{C}$ for $\sim 48 \mathrm{~h}$. The plates were removed from the anaerobic chamber and exposed to oxygen at room temperature for $24 \mathrm{~h}$. Cells were scraped from plates, suspended in 1X PBS and washed once. Spore suspensions were placed in flasks and exposed to oxygen at room temperature for 710 days to kill all vegetative cells. The surviving spores were subsequently rinsed twice with $1 \mathrm{X}$ PBS. The final spore stocks were enumerated on BHIS supplemented with $0.1 \%$ taurocholate and stored at a final concentration of either $1 \times 10^{7} \mathrm{CFU}$ $\mathrm{ml}^{-1}$ in $1 \mathrm{X}$ PBS supplemented with $1 \% \mathrm{BSA}$ to prevent

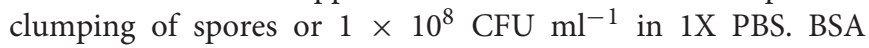
was omitted from the higher concentration spore stocks due to precipitation upon addition of some chemicals; however, the presence or absence of BSA did not affect the survival rates of spores in any tested condition. These spore stocks are stable at room temperature for at least a month (data not shown).

\section{Spore Resistance Assays}

Hundred microliter aliquots of $1 \times 10^{8} \mathrm{CFU} \mathrm{m}{ }^{-1}$ spores were incubated in the indicated concentration of chemicals for
15 min to ensure a final concentration of $1 \times 10^{7} \mathrm{CFU} \mathrm{ml} \mathrm{m}^{-1}$ spores, which is a concentration commonly used to test spore properties (Lawley et al., 2009). To test spore survival in a range of temperatures, $1 \mathrm{ml} 1 \times 10^{7} \mathrm{CFU} \mathrm{ml}^{-1}$ spores were placed in $8 \mathrm{ml}$ glass screw-cap tubes and incubated at the indicated temperature in a heated water bath for $20 \mathrm{~min}$. To test the efficacy of $\mathrm{NaOCl}$ in BHIS, $0.6 \mathrm{ml}$ spore aliquots in $1 \mathrm{X}$ PBS were pelleted at $15000 \mathrm{rpm}$ for $15 \mathrm{~min}$, and $0.55 \mathrm{ml}$ of supernatant was removed to minimize disruption of the spore pellet. Spores were subsequently suspended in equal volume BHIS and treated as described above. At the indicated times, serial dilutions were performed in 1X PBS and plated onto BHIS plates supplemented with $0.1 \%$ taurocholate. Colonies were enumerated from plates after a minimum of $36 \mathrm{~h}$ incubation.

\section{Phase Contrast Microscopy}

Phase contrast microscopy was performed as previously described (Edwards et al., 2014). Briefly, cultures were pelleted or cells were scraped off plates, suspended in $500 \mu \mathrm{l}$ BHIS and pelleted. The supernatant was decanted, and $2 \mu \mathrm{l}$ of cell suspension was placed on a prepared slide containing a thin $0.7 \%$ agarose pad. Phase contrast microscopy was performed using a X100 Ph3 oil immersion objection on a Nikon Eclipse $\mathrm{Ci}-\mathrm{L}$ microscope while images were captured using a DS-Fi2 camera.

\section{Statistical Analyses}

To evaluate the statistical significance, a two-way analysis of variance (ANOVA), followed by a Dunnett's multiple comparisons test, was used to compare the control to the concentration, length of time or temperature of the indicated conditions. To determine the significance of the germination frequency of purified spores, a one-way ANOVA was performed, followed by a Tukey's multiple comparisons test. $P \leq 0.05$ was considered statistically significant, and all statistical analyses were performed using Microsoft Excel or GraphPad Prism 6.

\section{Accession Numbers}

The accession numbers for strains used in this study are as follows: 630 (GenBank accession no. AM180355); R20291 (GenBank accession no. FN545816); M120 (078 reference strain; GenBank accession no. FN665653).

\section{RESULTS}

\section{Construction of a spo0A Mutant in 5325 (078 Ribotype)}

Because $C$. difficile is shed from the host as both vegetative cells and spores (Wilson et al., 1982; Koenigsknecht et al., 2015; Edwards et al., 2016), we first examined the sensitivities of vegetative cells to environmental stresses. $C$. difficile heterogeneously and asynchronously sporulates (Fimlaid et al., 2013). Thus, to ensure no spores were present in vegetative cell assays, we studied $C$. difficile mutants that are unable to form spores. The transcriptional regulator, Spo0A, serves as the 
master regulator of sporulation in all studied endospore-forming bacteria. Spo0A is required for the formation of spores and transmission of C. difficile (Deakin et al., 2012). To ensure all cells within a studied population were vegetative, we utilized a $630 \Delta \mathrm{erm}$ spo0A::erm mutant (hereafter referred to as 630 spo0A; MC310; 012 ribotype) and a R20291 spo0A::erm mutant (R20291 spo0A; 027 ribotype) (Dawson et al., 2012; Edwards et al., 2014). In addition, we created the same insertional mutation in the spo0A locus in 5325 (5325 spo0A; MC724; 078 ribotype). The insertion of a retargeted group II intron in the 5325 spo0A gene was confirmed by PCR amplification (Table 2; Supplementary Figure S1A). Further, phase contrast microscopy of the 5325 spo0A mutant revealed the absence of phase bright spores, indicating that the spoOA gene product was inactivated (Supplementary Figure S1B), matching the phenotype obtained in a previously published $s p o 0 A$ mutant in a 078 ribotype strain (Mackin et al., 2013).

\section{C. difficile Vegetative Cell and Spore Resistance to Ethanol}

Alcohol-based hand sanitizers containing $60-80 \%$ ethanol or isopropanol have emerged as a primary line of defense in preventing the transmission of infectious agents in healthcare settings. However, $C$. difficile spores are recalcitrant to alcohol exposure and are not removed from hands after use of alcohol rubs (Oughton et al., 2009; Edmonds et al., 2012; Nerandzic et al., 2015). To compare the resilience of $C$. difficile spores and vegetative cells to ethanol exposure, we first performed vegetative viability assays with the $s p o 0 A$ mutants in various concentrations of ethanol for 15 min. Both the 630 spo0A and R20291 spo0A numbers were reduced by $\sim 95 \%$ in $14.25 \%$ ethanol, whereas survival of the 5325 spo0A mutant was marginally affected at this concentration ( $\sim 35 \%$ reduction; Figure 1A). However, the vegetative cells of the three ribotypes tested were consistently reduced to undetectable levels in $28.5 \%$ ethanol, indicating that prolonged exposure to relatively high concentrations of alcohol can kill all $C$. difficile vegetative cells.

Depending on the methods used to isolate and purify spores, we have observed that brief ethanol or heat exposure (15-30 min) can enhance spore germination (data not shown). Based on these observations, we chose to isolate $C$. difficile spores following long-term exposure to oxygen, as described in "Materials and Methods," rather than by ethanol and/or heat exposure. This

TABLE 2 | Oligonucleotides.

\begin{tabular}{|c|c|c|}
\hline Primer & Sequence $\left(5^{\prime} \rightarrow 3^{\prime}\right)$ & $\begin{array}{l}\text { Use/locus } \\
\text { tag/reference }\end{array}$ \\
\hline oMC444 & 5'-GGAATACACAGGAGGTATCGTACA-3' & $\begin{array}{l}\text { Confirmation of } 5325 \\
\text { spoOA mutant }\end{array}$ \\
\hline oMC819 & 5'-GTGCGGCTGGATCACCTCCT-3' & $\begin{array}{l}\text { PCR ribotyping } \\
\text { (Bidet et al., 2000) }\end{array}$ \\
\hline oMC820 & 5'-CССTGCACCCTTAATAACTTGACC-3' & $\begin{array}{l}\text { PCR ribotyping } \\
\text { (Bidet et al., 2000) }\end{array}$ \\
\hline oMC1122 & 5'-AACCCTACTGGTTATACCGTTCG-3' & $\begin{array}{l}\text { Confirmation of } 5325 \\
\text { spoOA mutant }\end{array}$ \\
\hline
\end{tabular}

method reproducibly produced stocks with phase bright, viable spores containing no viable vegetative cells and some cell debris (Supplementary Figure S2). As previously demonstrated, C. difficile spores germinate efficiently in the presence of the bile salt, taurocholate, and the amino acid, glycine (Sorg and Sonenshein, 2008). Remarkably, we observed that regardless of the method used to eliminate vegetative cells, the 5325 (078 ribotype) spores consistently germinated and outgrew in medium lacking taurocholate at a much higher frequency $(\sim 75$-fold increase) than either the $630 \Delta \mathrm{erm}$ (012) or R20291 (027) spores (Table 3). This observation suggests that 5325 spores germinate using a taurocholate-independent mechanism, or more likely, that this strain has an increased ability to scavenge taurocholate from medium with components from animal by-products [i.e., brain-heart infusion (BHI) medium; see Discussion].

To measure $C$. difficile spore resistance to ethanol, concentrated spore stocks suspended in 1X PBS were mixed to the indicated final concentration of ethanol and incubated for $15 \mathrm{~min}$. The final concentration of spores in these assays was $1 \times 10^{7}$, which mimics the concentration used in a previous spore resistance study (Lawley et al., 2009) and closely reflects the number of CFUs enumerated from hamster feces during infection (Edwards et al., 2014, 2016). As previously reported (Lawley et al., 2009), C. difficile spores were extremely resistant to high levels of ethanol, with all strains exhibiting high survival rates $(\geq 50 \%)$ even in concentrations of ethanol as high as $85.5 \%$ (Figure 1B). Notably, the 5325 spores had higher survival rates in higher concentrations of ethanol than did the $630 \mathrm{\Delta erm}$ or R20291 spores, although this effect was not statistically significant ( $78 \%$ spore survival vs. $56 \%$ and $50 \%$, respectively, in $85.5 \%$ ethanol; Supplementary Figure S3). Altogether, these results indicate that $C$. difficile spore exposure to ethanol does not inactivate spores.

\section{C. difficile Resistance to Additional Organic Solvents}

Clostridium species and related organisms carry out solventogenesis, a process during which growth slows and solvents such as acetone, butanol, and ethanol are produced. For this reason, Clostridium and related organisms are used for the production of biofuels, including butanol, which generally inhibit microbial growth. As such, a frequent limiter for solvent production is the high level of solvent toxicity exhibited in relatively low concentrations (Ezeji et al., 2010). As solvent toxicity is understudied in $C$. difficile, we tested the susceptibility of $C$. difficile vegetative cells and spores to butanol as described in "Materials and Methods." Surprisingly, a significant number of the 5325 spo0A cells survived in $2.5 \%$ butanol compared to the 630 spo0A and R20291 spo0A strains (Figure 2A; 50\% survival versus 0.003 and $0.01 \%$ survival, respectively). While long-term viability and the ability to grow uninhibited in relatively high concentrations of butanol were not tested, these data suggest that the 5325 strain has the ability to withstand greater concentrations of butanol compared to other common C. difficile isolates. Spores of all three $C$. difficile strains demonstrated some sensitivity to increasing concentrations of butanol (Figure 2B). However, 



FIGURE 1 | Clostridium difficile vegetative cells are sensitive to ethanol, while spores are highly resistant to ethanol. (A) Survival of 630 spo0A, R20291 spoOA and 5325 spoOA vegetative cells grown to an $\mathrm{OD}_{600} \sim 1.0$ in BHIS medium and (B) $630 \Delta \mathrm{erm}$, R20291 and 5325 spores in 1X PBS after exposure to the indicated concentrations $(\mathrm{V} / \mathrm{V})$ of ethanol for $15 \mathrm{~min}$. The means and standard error of the means for at least three biological replicates are shown; the limit of detection equals $20 \mathrm{CFU} \mathrm{ml}{ }^{-1}$ for vegetative cells and $10 \mathrm{CFU} \mathrm{ml}{ }^{-1}$ for spores and is denoted by a dashed line. Asterisks indicate a $P$ value of $<0.05$ as determined by two-way ANOVA followed by a Dunnett's multiple comparisons test to compare the condition to the corresponding control of individual strains.

when spores were incubated with $50 \%$ butanol, the $630 \Delta \mathrm{erm}$ C. difficile spore CFU were reduced to $<1 \%$, compared to $\sim 13 \%$ and 19\% survival rates for the R20291 and 5325 spore populations, respectively, suggesting that the $630 \Delta \mathrm{erm}$ spores are more susceptible to butanol.

We also measured the sensitivity of $C$. difficile vegetative cells and spores to chloroform, an organic solvent sometimes used in sporulation assays for Bacillus subtilis and other clostridial organisms (Milhaud and Balassa, 1973; Schiott and Hederstedt, 2000; McBride and Haldenwang, 2004;

TABLE 3 | Germination frequency of $C$. difficile 012,027 , and 078 spores in the absence and presence of taurocholate.

\begin{tabular}{lcc}
\hline Strain & Ribotype & $\begin{array}{c}\text { Taurocholate-independent } \\
\text { germination frequency }\end{array}$ \\
\hline $630 \Delta$ erm & 012 & $2.04 \times 10^{-4} \pm 9.36 \times 10^{-5}$ \\
R20291 & 027 & $2.50 \times 10^{-4} \pm 2.24 \times 10^{-4}$ \\
5325 & 078 & $\mathbf{1 . 7 2} \times \mathbf{1 0}^{-\mathbf{2}} \pm \mathbf{9 . 0 5} \times \mathbf{1 0}^{-\mathbf{5}}$ \\
\hline
\end{tabular}

${ }^{a}$ Mean germination frequency is calculated from two independently prepared spore stocks as CFU $\mathrm{ml}^{-1}$ enumerated on BHIS divided by CFU $\mathrm{ml}^{-1}$ enumerated on BHIS supplemented with $0.1 \%$ taurocholate (total spores). Bold indicates $P<0.05$ as determined by a one-way ANOVA followed by Tukey's multiple comparisons test.
Tracy et al., 2011). The 5325 spo0A mutant demonstrated greater resistance to chloroform compared to the 630 spo0A and R20291 spo0A mutants, with $10 \%$ of the 5325 spo0A population surviving $1 \%$ chloroform exposure (Figure 2C), indicating that the 5325 vegetative cells are able to tolerate greater concentrations of chloroform. C. difficile spores were unaffected by chloroform exposure, but incubation in chloroform resulted in a small, but not statistically significant, increase in CFU in all strains (Figure 2D). However, this effect was not as consistent in higher concentrations of chloroform.

\section{C. difficile Resistance to Oxidative Stress}

Clostridium difficile vegetative cells are strict anaerobes and are known to be sensitive to low levels of oxygen (Holy and Chmelar, 2012). However, previous results in our lab demonstrated that some $C$. difficile vegetative cells present in hamster fecal samples survive at least $24 \mathrm{~h}$ in fecal pellets suspended in 1X PBS and stored aerobically (Edwards et al., 2016). These data led us to hypothesize that oxygen tolerance may be exhibited by C. difficile vegetative cells for short, but significant, periods of time. Although the transmission of non-sporulating $C$. difficile is almost eliminated in the mouse model of $C$. difficile infection (CDI) (Deakin et al., 2012), significant numbers of vegetative cells 


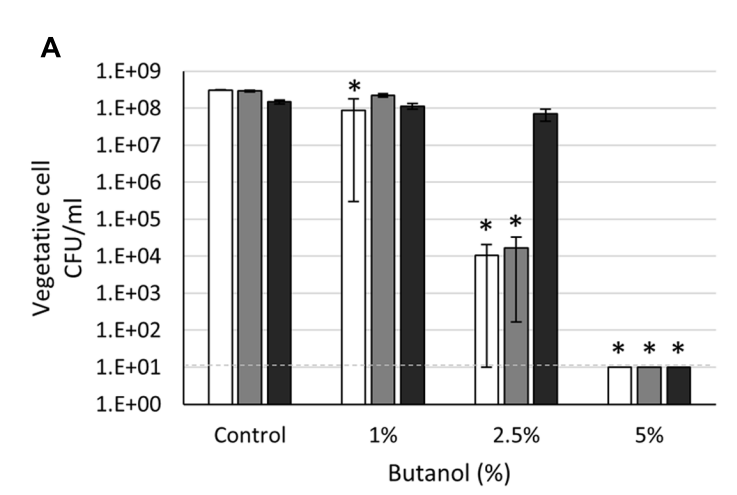

C

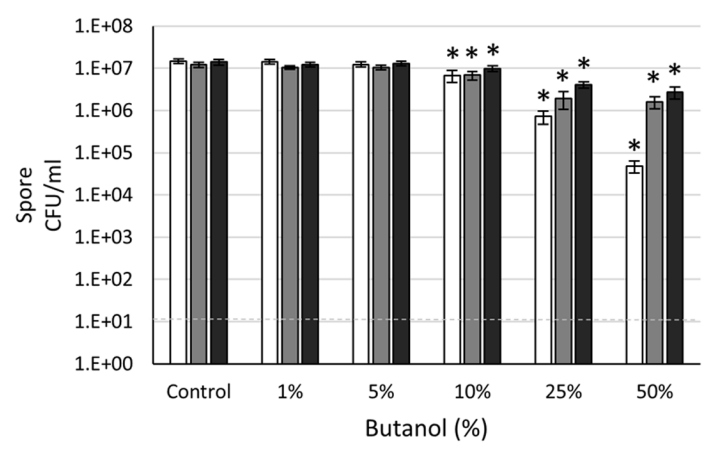

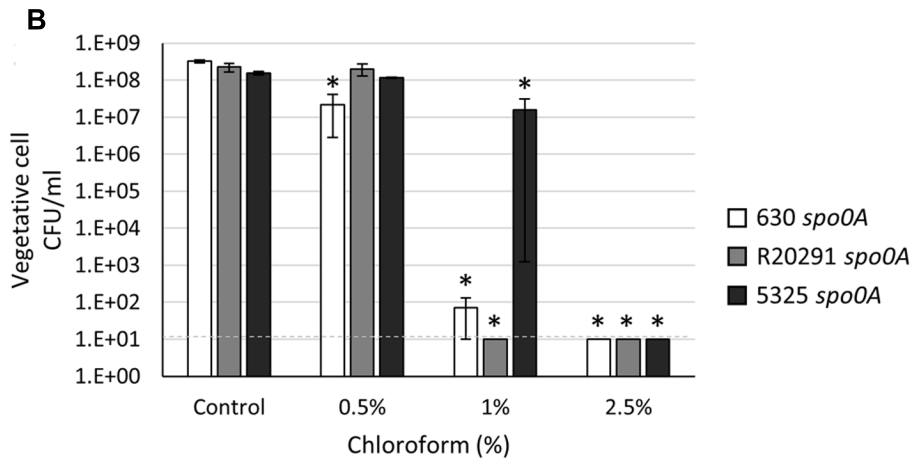

D

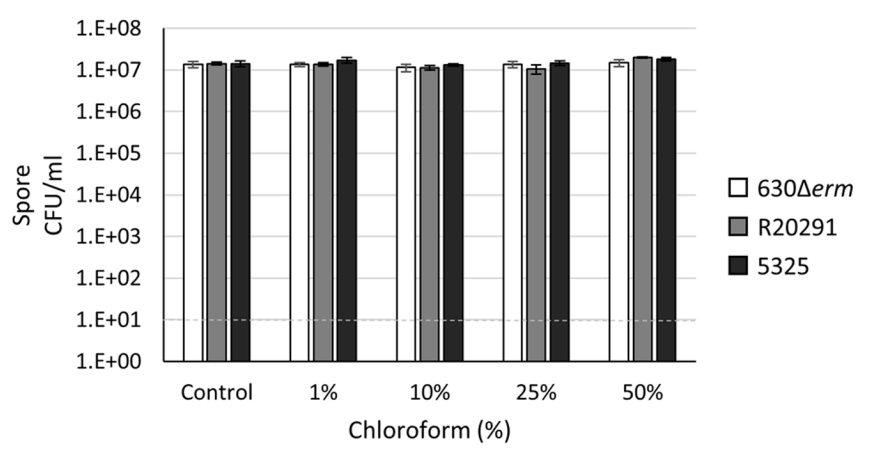

FIGURE 2 | Clostridium difficile 5325 vegetative cells exhibit greater resistance to solvents while R20291 spores are more sensitive to butanol. (A,C) Survival of 630 spo0A, R20291 spo0A and 5325 spo0A vegetative cells grown to an $\mathrm{OD}_{600} \sim 1.0$ in BHIS medium after a 15 min exposure to the indicated concentrations (V/V) of (A) butanol and (C) chloroform. (B,D) Survival of 630 $\Delta$ erm, R20291 and 5325 spores in 1 X PBS after a 15 min exposure to (B) butanol and (D) chloroform. The means and standard error of the means for at least three biological replicates are shown; the limit of detection is $10 \mathrm{CFU}$ ml ${ }^{-1}$ and is denoted by a dashed line. Asterisks indicate a $P$-value of $<0.05$ as determined by two-way ANOVA followed by a Dunnett's multiple comparisons test to compare the condition to the corresponding control of individual strains.

are shed and recovered in the stool (Koenigsknecht et al., 2015). It is unknown if vegetative cells play a role in transmission in clinical settings. To determine the extent of $C$. difficile vegetative cell oxygen tolerance, the spo0A mutant strains were grown to an $\mathrm{OD}_{600}$ of 1.0, plated for viability anaerobically and aliquots of the cultures were exposed to atmospheric oxygen for the indicated amount of time, serially diluted and plated anaerobically to enumerate surviving cells. As shown in Figure 3A, the 630 spo0A mutant strain was significantly more tolerant to atmospheric oxygen exposure than either the R20291 spo0A or 5325 spo0A mutant strains. R20291 spo0A and 5325 spo0A survival dropped precipitously after $1 \mathrm{~h}$ exposure to oxygen, and no surviving cells were recovered after $3 \mathrm{~h}$ oxygen exposure. These results demonstrate that the $630 \Delta \mathrm{erm}$ strain is able to survive brief oxygen exposure, perhaps providing additional opportunity for spread of the pathogen.

We next determined the effects of an important source of oxidative stress, the common antiseptic and oxidative burst component, hydrogen peroxide (Fawley et al., 2007; Slauch, 2011). Previous studies genetically linked the abilities for Clostridium acetobutylicum, a related anaerobe, to tolerate both oxygen and hydrogen peroxide exposures (Hillmann et al., 2008, 2009; Riebe et al., 2009). We asked whether C. difficile survival in oxygen correlates with hydrogen peroxide tolerance, as is observed with C. acetobutylicum. Spores from all three strains were resistant to up to $1.5 \%$ hydrogen peroxide (Supplementary Figure S4), confirming previous results performed with similar or unknown concentrations of hydrogen peroxide (Fawley et al., 2007; Lawley et al., 2010). In contrast, the vegetative cells of the 630 spo0A mutant exhibited increased resistance to hydrogen peroxide exposure compared to the R20291 spo0A and 5325 spo0A mutants (Figure 3B), similar to the atmospheric oxygen survival trials. These data suggest that the increased vegetative cell oxygen and hydrogen peroxide tolerance exhibited by the $630 \Delta \mathrm{erm}$ strain may be correlative, as in C. acetobutylicum.

\section{C. difficile Spores Tolerate High "Wet Heat" Temperatures for a Short Period of Time}

One advantage to bacterial spore formation is protection from extreme temperature variations. Wet heat resistance is the ability for spores to survive high temperatures when suspended in an aqueous solution (Setlow, 2006). This property is a universal characteristic of bacterial spores, but differences in heat tolerance between Bacillus and other spore-forming species have been noted (Murrell and Scott, 1966; Setlow, 2014). While B. subtilis spores can easily survive exposure to $80^{\circ} \mathrm{C}$ (Milhaud and 
A
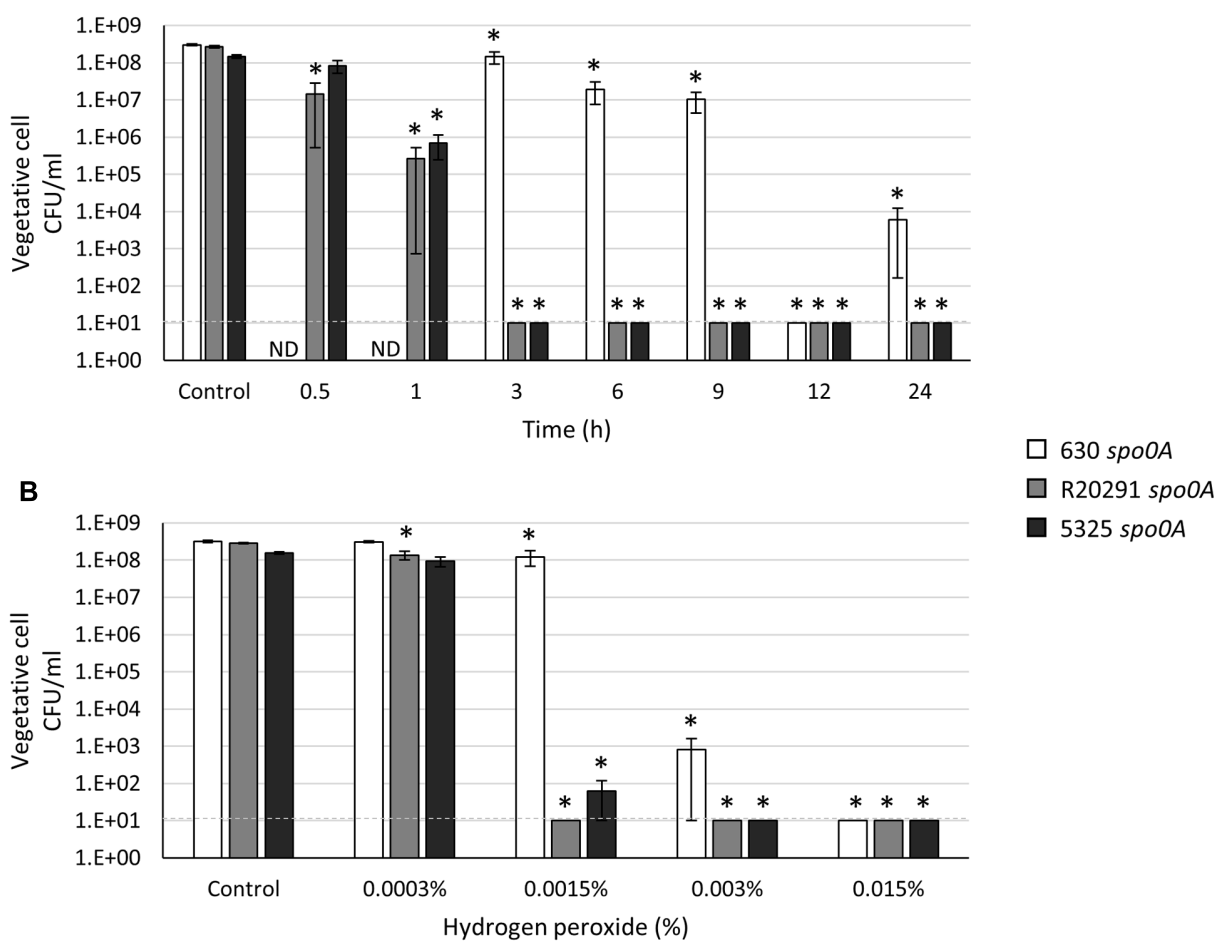

FIGURE 3 | Clostridium difficile 630 spoOA vegetative cells demonstrate greater resistance to oxidative stress. Survival of 630 spo0A, R20291 spo0A and 5325 spoOA vegetative cells grown to an $\mathrm{OD}_{600} \sim 1.0$ in BHIS medium after exposure to (A) atmospheric oxygen after the indicated length of time (h) or (B) hydrogen peroxide $\left(\mathrm{H}_{2} \mathrm{O}_{2}\right)$ for $15 \mathrm{~min}$. The means and standard error of the means for at least three biological replicates are shown; the limit of detection is $10 \mathrm{CFU}$ $\mathrm{ml}^{-1}$ and is denoted by a dashed line. Asterisks indicate a P-value of $<0.05$ as determined by two-way ANOVA followed by a Dunnett's multiple comparisons test to compare the condition to the corresponding control of individual strains. ND, not determined.

Balassa, 1973; Setlow, 2006; Leggett et al., 2012), previous studies in $C$. difficile have demonstrated that $C$. difficile spores are comparatively wet heat-labile (Lawley et al., 2009). C. difficile spores have been reported to withstand long-term exposure $\left(>24 \mathrm{~h}\right.$ ) to $60^{\circ} \mathrm{C}$ and up to $3 \mathrm{~h}$ at $70^{\circ} \mathrm{C}$ (Lawley et al., 2009), and wet heat-resistance assays are often used to select for $C$. difficile spores in a heterogenous population (Burns et al., 2011; ParedesSabja and Sarker, 2011; Fimlaid et al., 2015). We characterized the ability of $C$. difficile vegetative cells and spores to survive exposure to a range of wet heat temperatures for $20 \mathrm{~min}$. The number of $C$. difficile vegetative cells recovered after exposure to $60^{\circ} \mathrm{C}$ or greater temperature resulted in a $\sim 3-\log$ loss for all three strains; however, we variably recovered some viable vegetative cells following incubation in $80^{\circ} \mathrm{C}$ (Figure 4A). Exposure to $60^{\circ} \mathrm{C}$ resulted in a slight, but statistically insignificant, loss of spore viability for all strains (Figure 4B; Supplementary Figure S5). The loss of $630 \Delta \mathrm{erm}$ and 5325 spore viability was more pronounced from 65 to $75^{\circ} \mathrm{C}$ compared to R20291 spores, while all strains exhibited a significant decrease in spore recovery at $80^{\circ} \mathrm{C}$ (Figure 4B; Supplementary Figure S5). The R20291 spores exhibited a modest, but consistent, advantage in heat tolerance compared to the $630 \Delta \mathrm{erm}$ and 5325 spores (Figure 4B; Supplementary Figure S5). Viable spores were detectable from all three strains after exposure to $85^{\circ} \mathrm{C}$, although the spore load was reduced by at least $\sim 4$-logs, comparable to previous observations (Rodriguez-Palacios and Lejeune, 2011). These data indicate that a substantial proportion of $C$. difficile spores are susceptible to wet heat-killing at temperatures below $85^{\circ} \mathrm{C}$, but heat susceptibility is strain-dependent. These results should be taken into consideration when performing heat-resistance assays to quantitate sporulation within a population. Unsurprisingly, temperatures greater than $85^{\circ} \mathrm{C}$ are required to completely eliminate all $C$. difficile spores when in an aqueous environment.

\section{Household Bleach Is Effective in Eliminating Both C. difficile Vegetative Cells and Spores at an Alkaline pH but Loses Efficacy at a Neutral pH}

Sodium hypochlorite $(\mathrm{NaOCl})$, the active chemical present in household bleach, is one of the most effective and commonly recommended agents for general disinfection (McDonald et al., 2012). Household bleach is commercially available as an aqueous solution of $5.25-8.25 \% \mathrm{NaOCl}$, which correlates to a standard concentration of approximately 5000-8000 $\mathrm{mg} \mathrm{l}^{-1}$ free chlorine [FC or parts per million (ppm)]. Previous studies have demonstrated that acidified and household bleach significantly reduce or completely eliminate the number of $C$. difficile spores on hard surfaces (Perez et al., 2005; Alfa et al., 2010; Omidbakhsh, 2010). However, we asked whether household bleach was effective 


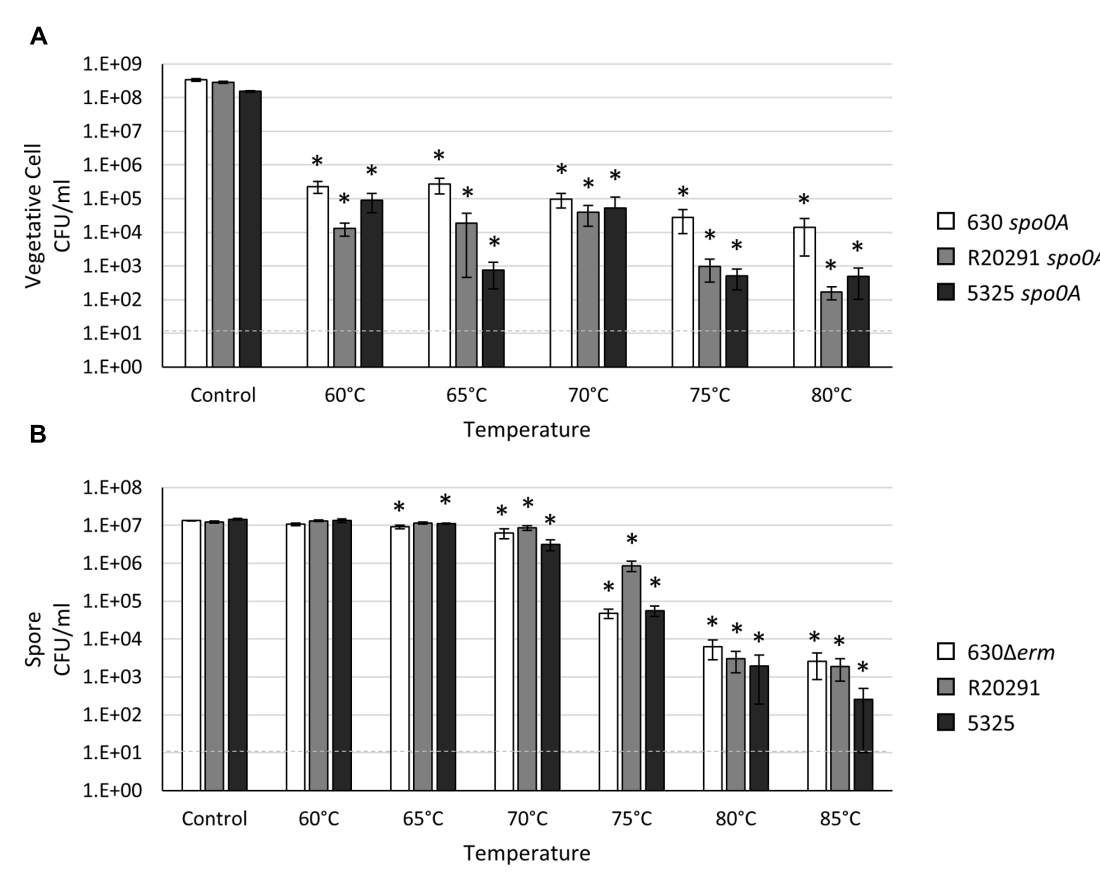

FIGURE 4 | Clostridium difficile spores are resistant to high temperatures. Survival of (A) 630 spo0A, R20291 spo0A and 5325 spo0A vegetative cells grown to an $\mathrm{OD}_{600} \sim 1.0$ in BHIS medium or (B) 630 $\Delta$ erm, R20291 and 5325 spores in 1X PBS after a 20 min exposure to the indicated temperature. The means and standard error of the means for at least three biological replicates are shown; the limit of detection is $10 \mathrm{CFU} \mathrm{ml}^{-1}$ and is denoted by a dashed line. Asterisks indicate a $P$-value of $<0.05$ as determined by two-way ANOVA followed by a Dunnett's multiple comparisons test to compare the condition to the corresponding control of individual strains.

in eliminating a high concentration of vegetative cells and spores in an aqueous suspension, as may be the case in some patient care situations. To first assess the microbicidal capacity of household bleach against $C$. difficile vegetative cells in suspension, we added household bleach at $400 \mathrm{mg} \mathrm{l}^{-1}, 1000 \mathrm{mg} \mathrm{l}^{-1}, 5000 \mathrm{mg} \mathrm{l}^{-1}$, and $8000 \mathrm{mg} \mathrm{l}^{-1} \mathrm{FC}$ (equivalent to $0.5,1.25,6.25$, and $10 \%$ bleach solutions) to the asporogenous population of the three C. difficile strains. As before, these strains were grown in the standard medium for cultivation, BHIS, $\mathrm{pH}$ 6.8. At an $\mathrm{OD}_{600}$ of 1.0 , the $\mathrm{pH}$ of the culture was $5.98 \pm 0.04$. When bleach was added to the culture, the $\mathrm{pH}$ was increased in a dose-dependent manner, favoring hypochlorite $\left(\mathrm{ClO}^{-}\right)$formation [final culture $\mathrm{pH}=6.04 \pm 0.04$ in $400 \mathrm{mg} \mathrm{l}^{-1}(0.5 \%)$ household bleach; final culture $\mathrm{pH}=6.60 \pm 0.02$ in $5000 \mathrm{mg} \mathrm{l}^{-1}$ (6.25\%) household bleach.] After a $15 \mathrm{~min}$ incubation in $400 \mathrm{mg} \mathrm{l}^{-1}(0.5 \%)$ household bleach, the vegetative cell population of all three strains was decreased by $\sim 85-90 \%$ (Figure 5A). Few vegetative cells were recoverable after incubation in $1000 \mathrm{mg} \mathrm{l}^{-1}(1.25 \%)$ and $5000 \mathrm{mg}^{-1}$ (6.25\%) household bleach, and viable C. difficile cells were reduced to below the limit of detection $(<10 \mathrm{CFU}$ $\mathrm{ml}^{-1}$ ) in $8000 \mathrm{mg} \mathrm{l}^{-1}(10 \%)$ household bleach (Figure 5A). As $\mathrm{pH}$ alters the ratio of hypochlorite $(\mathrm{HOCl})$ to the hypochlorite ion $\left(\mathrm{OCl}^{-}\right)$, and thus, the effectiveness of bleach (Baumann and Ludwig, 1962), these data suggested that the $\mathrm{pH}$ of the aqueous solution may alter the effectiveness of sodium hypochlorite. To test this hypothesis, vegetative cells grown to an $\mathrm{OD}_{600}$ of 1.0 in BHIS medium were pelleted and suspended in pre-reduced 1X PBS ( $\mathrm{pH} 7.4$ ). The addition of household bleach to 1X PBS resulted in an alkaline suspension ( $\mathrm{pH}$ 8.4-10, depending on the final concentration of bleach). A 15 min incubation in household bleach at all concentrations reduced the number of recoverable viable vegetative cells to below the limit of detection $(<10 \mathrm{CFU}$ $\mathrm{ml}^{-1}$; data not shown).

We next determined the efficacy of household bleach against C. difficile spores suspended in either 1X PBS or BHIS medium. As with $C$. difficile vegetative cells suspended in $1 X$ PBS, a $15 \mathrm{~min}$ exposure to all concentrations of bleach was effective in reducing viable spores to below the limit of detection $\left(<10 \mathrm{CFU} \mathrm{ml}{ }^{-1}\right.$; data not shown). Surprisingly, C. difficile 630 $\Delta \mathrm{erm}$, R20291 and 5325 spores suspended in BHIS were able to withstand a $15 \mathrm{~min}$ exposure to household bleach, even at the highest concentration of $8000 \mathrm{mg} \mathrm{l}^{-1}$ (10\%) household bleach (Figure 5B). These data suggest that the $\mathrm{pH}$ of liquid biohazard spills (e.g., feces) may alter the effectiveness of sodium hypochlorite. As a result, higher concentrations of bleach and/or the use of additional components to ensure an alkaline $\mathrm{pH}$ may be necessary to completely eliminate $C$. difficile vegetative cells and spores in biohazard spills.

\section{DISCUSSION}

Clostridium difficile infections have quickly emerged as a significant healthcare burden, and result in billions of dollars per year in additional healthcare-related expenses (Kwon et al., 2015; Levy et al., 2015). The environmental reduction of 

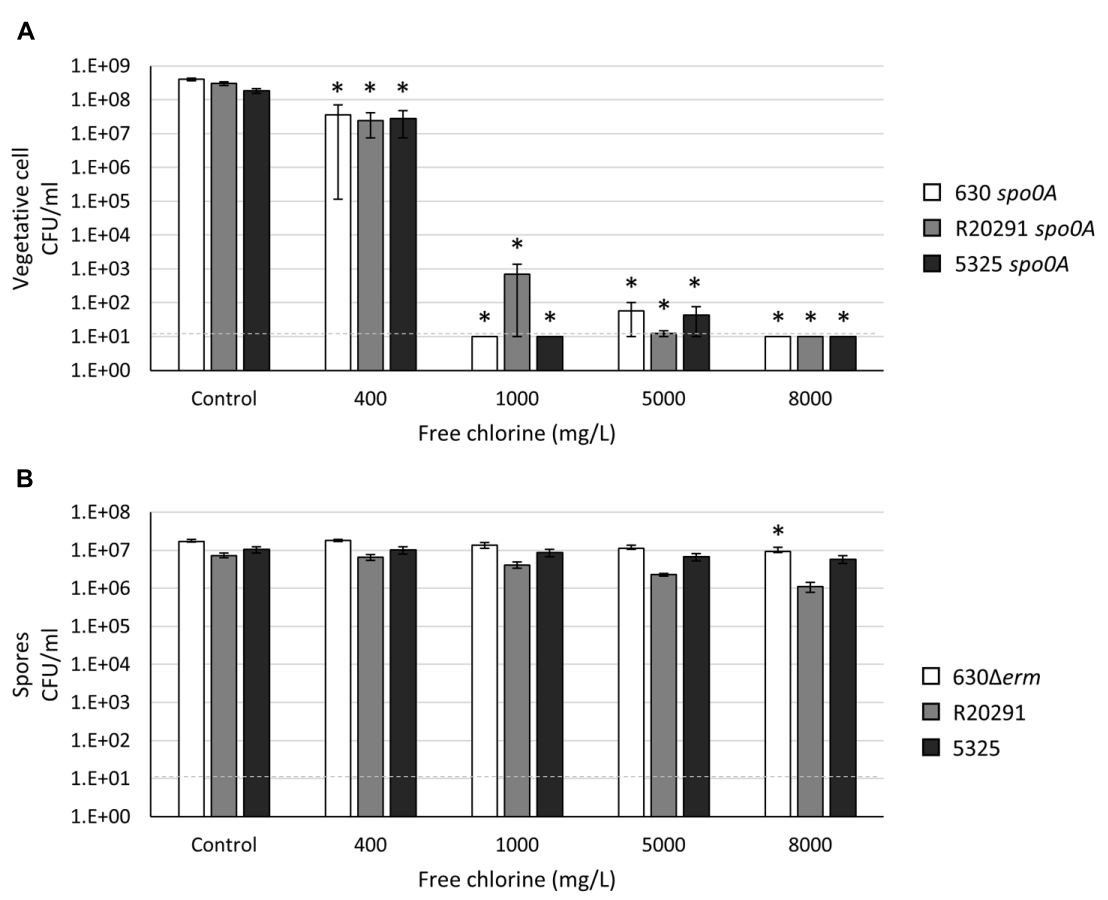

FIGURE 5 | Clostridium difficile vegetative cells and spores are resistant to sodium hypochlorite (household bleach) at a physiological pH. Survival of (A) 630 spoOA, R20291 spoOA and 5325 spoOA vegetative cells grown to an OD $600 \sim 1.0$ in BHIS medium or (B) $630 \Delta$ erm, R20291 and 5325 spores suspended in BHIS medium after exposure to $400 \mathrm{mg} \mathrm{l}^{-1}, 1000 \mathrm{mg} \mathrm{l}^{-1}, 5000 \mathrm{mg} \mathrm{l}^{-1}$, $8000 \mathrm{mg} \mathrm{l}^{-1}$ free chlorine (FC) for 15 min. The means and standard error of the means for at least three biological replicates are shown; the limit of detection is $10 \mathrm{CFU} \mathrm{ml}{ }^{-1}$ and is denoted by a dashed line. Asterisks indicate a $P$-value of $<0.05$ as determined by two-way ANOVA followed by a Dunnett's multiple comparisons test to compare the condition to the corresponding control of individual strains.

C. difficile spores is a major concern in the prevention of efficient transmission in hospitals and acute and long-term care facilities. While sodium hypochlorite (household bleach) has traditionally been recommended for sanitization in these settings, studies have shown that without frequent and thorough cleaning, detection and transmission of $C$. difficile can occur (Macleod-Glover and Sadowski, 2010; Lessa et al., 2012). To better understand how the resistance properties of $C$. difficile could impact survival and transmission, this study investigated the persistence of vegetative cells and spores after exposure of different $C$. difficile strains to a variety of chemicals and temperatures.

As expected, we observed greater effects for all of the chemicals and conditions tested on the viability of vegetative cells, compared to that of spores. The highest concentrations of ethanol $(28.5 \%)$, butanol $(5 \%)$, chloroform $(2.5 \%)$, hydrogen peroxide $(0.015 \%)$ or bleach $\left(8000 \mathrm{mg} \mathrm{l}^{-1}\right)$ tested were sufficient to decrease the vegetative cell counts for all strains to below detectable limits $(\sim 10 \mathrm{CFU} / \mathrm{ml})$. But, some treatments were more effective against vegetative cells of some strains than others. In particular, the 630 spo0A strain demonstrated higher resistance to oxygen exposure and hydrogen peroxide than the R20291 spo0A and 5325 spo0A strains examined. Conversely, the 5325 spo0A strain displayed greater resistance to killing by the organic compounds butanol and chloroform than the 630 spo0A and R20291 spo0A strains. These results reveal strain-dependent differences in survival that are specific to actively growing cells and independent of spore structure. Because C. difficile spo0A mutants exhibit pleiotropic phenotypes, we tested the 630 spo0A isogenic parent, $630 \Delta \mathrm{erm}$, in a subset of conditions, and found no difference in survival rates (Supplementary Figure S6), indicating that the spo0A mutant strain behaves similarly to the parent strain.

To our knowledge, aerotolerance of $C$. difficile vegetative cells has not been mechanistically studied. The observation that oxygen sensitivity and hydrogen peroxide resistance are straindependent properties may provide insight into the mechanisms by which $C$. difficile tolerates low levels of oxidative stress. A mutation in the oxidative stress repressor (perR) in the related organism, Clostridium acetobutylicum, confers prolonged aerotolerance and higher resistance to hydrogen peroxide $\left(\mathrm{H}_{2} \mathrm{O}_{2}\right.$; Hillmann et al., 2008). A single genetic pathway in C. acetobutylicum, which includes PerR, is responsible for detoxifying both atmospheric oxygen and reactive oxygen species (ROS), including those produced by hydrogen peroxide (Riebe et al., 2009). Although C. acetobutylicum is more aerotolerant than $C$. difficile, the fact that resistance to oxygen exposure and ROS correlates with individual strains suggests that $C$. difficile may also utilize a single genetic pathway to combat multiple sources of oxidative stress. The infectious dose of $C$. difficile is unknown, but is presumed to be extremely low $(<10)$, as is observed for the hamster model of acute CDI (Larson et al., 1978). Consequently, it is possible that vegetative cells play a minor role in the spread of $C$. difficile if vegetative cells from feces can survive short periods of exposure to atmospheric oxygen. 
As anticipated, spores of all three strains were inherently resistant to many of the chemicals tested, with ethanol, chloroform and hydrogen peroxide proving ineffective at any practical concentration that could be assessed. Strain-dependent differences were observed for spore resistance to butanol, which was more effective against strain $630 \Delta \mathrm{erm}$, and wet heat, which more readily killed $630 \Delta \mathrm{erm}$ and 5325 . The highest wet-heat temperature examined, $85^{\circ} \mathrm{C}$, was not sufficient to completely destroy all spores for any of the strains examined.

As environmental control is one of the critical measures in preventing the spread of CDI, the use of the most effective cleaning products, along with adequate cleaning procedures (Eckstein et al., 2007), is necessary to reduce the environmental sources of C. difficile spores (Macleod-Glover and Sadowski, 2010). Our results confirm that spores are recalcitrant to high concentrations of ethanol, the primary active ingredient in alcohol-based hand sanitizers, and relatively high concentrations of hydrogen peroxide $(<3 \%)$, which is an active ingredient in several hospital cleaning agents. A previous study demonstrated that $1 \%$ hydrogen peroxide can reduce spore viability by $\sim 75 \%$ when incubated with $10^{6}$ spores $/ \mathrm{ml}$. We observed $\sim 25-40 \%$ reduction that was not statistically significant (Supplementary Figure S4), and we used a higher concentration of spores in our tests $\left(10^{6}\right.$ vs. $10^{7}$ spore CFU/ml) (Lawley et al., 2010). Further, Lawley et al. (2010) found that exposure to a 10\% hydrogen peroxide solution reduced viable spores to below their limit of detection $\left(<2 \mathrm{CFU} \mathrm{ml} \mathrm{ml}^{-1}\right.$ ). Some studies have shown that the use of hydrogen peroxide-based hospital cleaning agents [e.g., G-force, accelerated hydrogen peroxide (AHP) and stabilized hydrogen peroxide (SHP)] in clinical settings can reduce, but not completely eliminate, detection of $C$. difficile or patient cases of CDI (Alfa et al., 2010; Horn and Otter, 2015; Steindl et al., 2015). Because spores are highly resistant to these compounds in the laboratory and strong, stable solutions of hydrogen peroxide are necessary for spore inactivation, our results strongly suggest that these products not be used for decontamination, and confirm that a strong dilution of household bleach at an alkaline $\mathrm{pH}$ is the best choice for environmental control of $C$. difficile (Wilcox et al., 2003; Eckstein et al., 2007).

We observed that spores of the 5325 strain appeared to germinate in a taurocholate-independent manner on BHIS plates at a significantly higher frequency than $630 \Delta \mathrm{erm}$ or R20291 spores. Other $C$. difficile clinical isolates have exhibited germination in the absence of bile salts, and no correlation between ribotypes was noted (Heeg et al., 2012). However, these spores were heat treated at $60^{\circ} \mathrm{C}$ for 25 min before plating, which may increase the germination frequency (Rodriguez-Palacios and Lejeune, 2011). A recent study revealed that all tested $C$. difficile strains, including those in the previous study that germinated and resumed growth in medium lacking taurocholate, required taurocholate and glycine to germinate in vitro, with the exception of CD 2351, a 078 clinical isolate, which did not require glycine (Bhattacharjee et al., 2016). Further, some spores exhibited a significantly increased affinity to taurocholate (Bhattacharjee et al., 2016), suggesting that spores from these strains require lower concentrations of taurocholate to activate germination. Thus, the difference in frequencies of taurocholate-independent germination by 5325 compared to $630 \Delta \mathrm{erm}$ and R20291 may result from an increased ability for 5325 to bind low levels of taurocholate. The variation in affinity to bile salts of various C. difficile clinical isolates may reflect the availability of nutrients and ratio of bile salts present in the primary host GI tract.

This study further highlights the broad variations observed in $C$. difficile clinical and animal isolates in regards to many physiological processes, including sporulation, germination and toxin production (Burns et al., 2010; Heeg et al., 2012; Carlson et al., 2015; Nawrocki et al., 2015; Bhattacharjee et al., 2016). Although an attractive hypothesis is that the distinct properties of each strain are genotypic and reflect the GI environment of the primary host in which each strain evolved, there are likely many variable environmental factors that contribute to the physical composition of the spore, such as the prominence of different spore proteins and the number of germinant receptors.

Further studies are required to determine which features of the $C$. difficile spore coat and cortex confer resistance to various chemicals and environmental insults. Resistances often arise sequentially, not simultaneously, as additional components are built onto the prespore, as seen in B. subtilis (Balassa, 1971; Russell, 1990). Determining the order of resistances as C. difficile sporulation progresses will provide insight into the biochemical mechanisms of spore formation and may serve as a useful tool for studying late sporulation events.

\section{AUTHOR CONTRIBUTIONS}

AE, SK, RP, LJ, SA, and SM contributed to the acquisition and analysis of the data. AE drafted the manuscript and AE, SK, RP, LJ, SA, and SM edited and approved the content.

\section{FUNDING}

This research was supported by the U.S. National Institutes of Health (NIH) through grants AI116933, AI109526, DK087763 and DK101870 to SM, AI106699 to SA, and GM099644 to RP. The content of this manuscript is solely the responsibility of the authors and does not necessarily reflect the official views of the National Institutes of Health.

\section{ACKNOWLEDGMENTS}

We thank the members of the McBride lab for helpful suggestions and discussions throughout the course of this study. We are grateful to Brendan Wren for the gift of the R20291 spo0A mutant and to Aimee Shen for the spo0A plasmid.

\section{SUPPLEMENTARY MATERIAL}

The Supplementary Material for this article can be found online at: http://journal.frontiersin.org/article/10.3389/fmicb.2016. 01698/full\#supplementary-material 


\section{REFERENCES}

Alfa, M. J., Lo, E., Wald, A., Dueck, C., DeGagne, P., and Harding, G. K. (2010). Improved eradication of Clostridium difficile spores from toilets of hospitalized patients using an accelerated hydrogen peroxide as the cleaning agent. BMC Infect. Dis 10:268. doi: 10.1186/1471-2334-10-268

Ali, S., Moore, G., and Wilson, A. P. (2011). Spread and persistence of Clostridium difficile spores during and after cleaning with sporicidal disinfectants. J. Hosp. Infect. 79, 97-98. doi: 10.1016/j.jhin.2011.06.010

Balassa, G. (1971). The genetic control of spore formation in bacilli. Curr. Top. Microbiol. Immunol 56, 99-192.

Baumann, E. R., and Ludwig, D. D. (1962). Free available chlorine residuals for small nonpublic water supplies. J. Am. Water Works Assoc. 54, 1379-1388.

Bhattacharjee, D., Francis, M. B., Ding, X., McAllister, K. N., Shrestha, R., and Sorg, J. A. (2016). Reexamining the germination phenotypes of several Clostridium difficile strains suggests another role for the CspC germinant receptor. J. Bacteriol. 198, 777-786. doi: 10.1128/JB.00908-915

Bidet, P., Lalande, V., Salauze, B., Burghoffer, B., Avesani, V., Delmee, M., et al. (2000). Comparison of PCR-ribotyping, arbitrarily primed PCR, and pulsedfield gel electrophoresis for typing Clostridium difficile. J. Clin. Microbiol. 38, 2484-2487.

Bouillaut, L., McBride, S. M., and Sorg, J. A. (2011). Genetic manipulation of Clostridium difficile. Curr Protoc Microbiol. Chap. 9, Unit9A.2. doi: 10.1002/9780471729259.mc09a02s20

Burns, D. A., Heap, J. T., and Minton, N. P. (2010). The diverse sporulation characteristics of Clostridium difficile clinical isolates are not associated with type. Anaerobe 16, 618-622. doi: 10.1016/j.anaerobe.2010.10.001

Burns, D. A., Heeg, D., Cartman, S. T., and Minton, N. P. (2011). Reconsidering the sporulation characteristics of hypervirulent Clostridium difficile BI/NAP1/027. PLoS ONE 6:e24894. doi: 10.1371/journal.pone.0024894

Carlson, P. E. Jr., Kaiser, A. M., McColm, S. A., Bauer, J. M., Young, V. B., Aronoff, D. M., et al. (2015). Variation in germination of Clostridium difficile clinical isolates correlates to disease severity. Anaerobe 33, 64-70. doi: 10.1016/j.anaerobe.2015.02.003

CDC (2013). Antibiotic Resistance Threats in the United States, 2013. Available at: http://www.cdc.gov/features/AntibioticResistanceThreats/

Dawson, L. F., Valiente, E., Faulds-Pain, A., Donahue, E. H., and Wren, B. W. (2012). Characterisation of Clostridium difficile biofilm formation, a role for Spo0A. PLoS ONE 7:e50527. doi: 10.1371/journal.pone.0050527

de Hoon, M. J., Eichenberger, P., and Vitkup, D. (2010). Hierarchical evolution of the bacterial sporulation network. Curr. Biol. 20, R735-R745. doi: 10.1016/j.cub.2010.06.031

Deakin, L. J., Clare, S., Fagan, R. P., Dawson, L. F., Pickard, D. J., West, M. R., et al. (2012). The Clostridium difficile spo0A gene is a persistence and transmission factor. Infect. Immun. 80, 2704-2711. doi: 10.1128/IAI.00147-12

Driks, A. (2002). Overview: development in bacteria: spore formation in Bacillus subtilis. Cell. Mol. Life Sci. 59, 389-391. doi: 10.1007/s00018-002-8430-x

Driks, A. (2003). The dynamic spore. Proc. Natl. Acad. Sci. U.S.A. 100, 3007-3009. doi: 10.1073/pnas.0730807100

Dubberke, E. (2012). Strategies for prevention of Clostridium difficile infection. J. Hosp. Med. 7(Suppl. 3), S14-S17. doi: 10.1002/jhm.1908

Dubberke, E. R., and Olsen, M. A. (2012). Burden of Clostridium difficile on the healthcare system. Clin. Infect. Dis. 55(Suppl. 2), S88-S92. doi: $10.1093 / \mathrm{cid} / \mathrm{cis} 335$

Eckstein, B. C., Adams, D. A., Eckstein, E. C., Rao, A., Sethi, A. K., Yadavalli, G. K., et al. (2007). Reduction of Clostridium difficile and vancomycin-resistant Enterococcus contamination of environmental surfaces after an intervention to improve cleaning methods. BMC Infect. Dis. 7:61. doi: 10.1186/1471-2334-7-61

Edmonds, S. L., Macinga, D. R., Mays-Suko, P., Duley, C., Rutter, J., Jarvis, W. R., et al. (2012). Comparative efficacy of commercially available alcohol-based hand rubs and World Health Organization-recommended hand rubs: formulation matters. Am. J. Infect. Control 40, 521-525. doi: 10.1016/j.ajic.2011.08.016

Edwards, A. N., Nawrocki, K. L., and McBride, S. M. (2014). Conserved oligopeptide permeases modulate sporulation initiation in Clostridium difficile. Infect. Immun. 82, 4276-4291. doi: 10.1128/IAI.02323-14

Edwards, A. N., Suarez, J. M., and McBride, S. M. (2013). Culturing and maintaining Clostridium difficile in an anaerobic environment. J. Vis. Exp. 79, e50787. doi: $10.3791 / 50787$
Edwards, A. N., Tamayo, R., and McBride, S. M. (2016). A novel regulator controls Clostridium difficile sporulation, motility and toxin production. Mol. Microbiol. 100, 954-971. doi: 10.1111/mmi.13361

Ezeji, T., Milne, C., Price, N. D., and Blaschek, H. P. (2010). Achievements and perspectives to overcome the poor solvent resistance in acetone and butanolproducing microorganisms. Appl. Microbiol. Biotechnol. 85, 1697-1712. doi: 10.1007/s00253-009-2390-0

Fawley, W. N., Underwood, S., Freeman, J., Baines, S. D., Saxton, K., Stephenson, K., et al. (2007). Efficacy of hospital cleaning agents and germicides against epidemic Clostridium difficile strains. Infect. Control Hosp. Epidemiol. 28, 920-925. doi: 10.1086/519201

Fimlaid, K. A., Bond, J. P., Schutz, K. C., Putnam, E. E., Leung, J. M., Lawley, T. D., et al. (2013). Global analysis of the sporulation pathway of Clostridium difficile. PLoS Genet. 9:e1003660. doi: 10.1371/journal.pgen.1003660

Fimlaid, K. A., Jensen, O., Donnelly, M. L., Francis, M. B., Sorg, J. A., and Shen, A. (2015). Identification of a novel lipoprotein regulator of Clostridium difficile spore germination. PLoS Pathog. 11:e1005239. doi: 10.1371/journal.ppat.1005239

Francis, M. B., Allen, C. A., Shrestha, R., and Sorg, J. A. (2013). Bile acid recognition by the Clostridium difficile germinant receptor, CspC, is important for establishing infection. PLoS Pathog. 9:e1003356. doi: 10.1371/journal.ppat.1003356

Heeg, D., Burns, D. A., Cartman, S. T., and Minton, N. P. (2012). Spores of Clostridium difficile clinical isolates display a diverse germination response to bile salts. PLoS ONE 7:e32381. doi: 10.1371/journal.pone.0032381

Henriques, A. O., and Moran, C. P. Jr. (2007). Structure, assembly, and function of the spore surface layers. Annu. Rev. Microbiol. 61, 555-588. doi: 10.1146/annurev.micro.61.080706.093224

Hillmann, F., Doring, C., Riebe, O., Ehrenreich, A., Fischer, R. J., and Bahl, H. (2009). The role of PerR in O2-affected gene expression of Clostridium acetobutylicum. J. Bacteriol. 191, 6082-6093. doi: 10.1128/JB.00351-09

Hillmann, F., Fischer, R. J., Saint-Prix, F., Girbal, L., and Bahl, H. (2008). PerR acts as a switch for oxygen tolerance in the strict anaerobe Clostridium acetobutylicum. Mol. Microbiol. 68, 848-860. doi: 10.1111/j.13652958.2008.06192.x

Ho, T. D., and Ellermeier, C. D. (2011). PrsW is required for colonization, resistance to antimicrobial peptides, and expression of extracytoplasmic function sigma factors in Clostridium difficile. Infect. Immun. 79, 3229-3238. doi: 10.1128/IAI.00019-11

Holy, O., and Chmelar, D. (2012). Oxygen tolerance in anaerobic pathogenic bacteria. Folia Microbiol. (Praha) 57, 443-446. doi: 10.1007/s12223-0120149-y

Horn, K., and Otter, J. A. (2015). Hydrogen peroxide vapor room disinfection and hand hygiene improvements reduce Clostridium difficile infection, methicillin-resistant Staphylococcus aureus, vancomycin-resistant enterococci, and extended-spectrum beta-lactamase. Am. J. Infect. Control 43, 1354-1356. doi: 10.1016/j.ajic.2015.06.029

Hussain, H. A., Roberts, A. P., and Mullany, P. (2005). Generation of an erythromycin-sensitive derivative of Clostridium difficile strain $630(630 \Delta \mathrm{erm})$ and demonstration that the conjugative transposon $\mathrm{Tn} 916 \Delta \mathrm{E}$ enters the genome of this strain at multiple sites. J. Med. Microbiol. 54, 137-141. doi: 10.1099/jmm.0.45790-0

Janoir, C. (2016). Virulence factors of Clostridium difficile and their role during infection. Anaerobe 37, 13-24. doi: 10.1016/j.anaerobe.2015.10.009

Koenigsknecht, M. J., Theriot, C. M., Bergin, I. L., Schumacher, C. A., Schloss, P. D., and Young, V. B. (2015). Dynamics and establishment of Clostridium difficile infection in the murine gastrointestinal tract. Infect. Immun. 83, 934-941. doi: 10.1128/IAI.02768-14

Kwon, J. H., Olsen, M. A., and Dubberke, E. R. (2015). The morbidity, mortality, and costs associated with Clostridium difficile infection. Infect. Dis. Clin. North Am. 29, 123-134. doi: 10.1016/j.idc.2014.11.003

Larson, H. E., Price, A. B., Honour, P., and Borriello, S. P. (1978). Clostridium difficile and the aetiology of pseudomembranous colitis. Lancet 1, 1063-1066. doi: 10.1016/S0140-6736(78)90912-1

Lawley, T. D., Clare, S., Deakin, L. J., Goulding, D., Yen, J. L., Raisen, C., et al. (2010). Use of purified Clostridium difficile spores to facilitate evaluation of health care disinfection regimens. Appl. Environ. Microbiol. 76, 6895-6900. doi: 10.1128/AEM.00718-10 
Lawley, T. D., Croucher, N. J., Yu, L., Clare, S., Sebaihia, M., Goulding, D., et al. (2009). Proteomic and genomic characterization of highly infectious Clostridium difficile 630 spores. J. Bacteriol. 191, 5377-5386. doi: 10.1128/JB.00597-09

Leggett, M. J., McDonnell, G., Denyer, S. P., Setlow, P., and Maillard, J. Y. (2012). Bacterial spore structures and their protective role in biocide resistance. J. Appl. Microbiol. 113, 485-498. doi: 10.1111/j.1365-2672.2012.05336.x

Lessa, F. C., Gould, C. V., and McDonald, L. C. (2012). Current status of Clostridium difficile infection epidemiology. Clin. Infect. Dis. 55(Suppl. 2), S65-S70. doi: 10.1093/cid/cis319

Levy, A. R., Szabo, S. M., Lozano-Ortega, G., Lloyd-Smith, E., Leung, V., Lawrence, R., et al. (2015). Incidence and costs of Clostridium difficile infections in Canada. Open Forum Infect. Dis. 2, ofv076. doi: 10.1093/ofid/ofv076

Mackin, K. E., Carter, G. P., Howarth, P., Rood, J. I., and Lyras, D. (2013). Spo0A differentially regulates toxin production in evolutionarily diverse strains of Clostridium difficile. PLoS ONE 8:e79666. doi: 10.1371/journal.pone.0079666

Macleod-Glover, N., and Sadowski, C. (2010). Efficacy of cleaning products for C. difficile: environmental strategies to reduce the spread of Clostridium difficileassociated diarrhea in geriatric rehabilitation. Can. Fam. Physician 56, 417-423.

McBride, S., and Haldenwang, W. G. (2004). Sporulation phenotype of a Bacillus subtilis mutant expressing an unprocessable but active sigmaE transcription factor. J. Bacteriol. 186, 1999-2005. doi: 10.1128/JB.186.7.1999-2005.2004

McDonald, L. C., Lessa, F., Sievert, D., Wise, M., Herrera, R., Gould, C., et al. (2012). Vital signs: preventing Clostridium difficile infections. Morb. Mortal. Wkly. Rep. 61, 157-162.

Milhaud, P., and Balassa, G. (1973). Biochemical genetics of bacterial sporulation. IV. Sequential development of resistances to chemical and physical agents during sporulation of Bacillus subtilis. Mol. Gen. Genet. 125, 241-250. doi: 10.1007/BF00270746

Murrell, W. G., and Scott, W. J. (1966). The heat resistance of bacterial spores at various water activities. J. Gen. Microbiol. 43, 411-425. doi: 10.1099/0022128743-3-411

Nawrocki, K. L., Edwards, A. N., Daou, N., Bouillaut, L., and McBride, S. M. (2015). CodY-dependent regulation of sporulation in Clostridium difficile. J. Bacteriol. 198, 2113-2130. doi: 10.1128/JB.00220-16,

Nerandzic, M. M., Sunkesula, V. C. C. T. S., Setlow, P., and Donskey, C. J. (2015). Unlocking the sporicidal potential of ethanol: induced sporicidal activity of ethanol against Clostridium difficile and Bacillus Spores under altered physical and chemical conditions. PLOS ONE 10:e0132805. doi: 10.1371/journal.pone.0132805

Omidbakhsh, N. (2010). Evaluation of sporicidal activities of selected environmental surface disinfectants: carrier tests with the spores of Clostridium difficile and its surrogates. Am. J. Infect. Control 38, 718-722. doi: 10.1016/j.ajic.2010.02.009

Oughton, M. T., Loo, V. G., Dendukuri, N., Fenn, S., and Libman, M. D. (2009). Hand hygiene with soap and water is superior to alcohol rub and antiseptic wipes for removal of Clostridium difficile. Infect. Control Hosp. Epidemiol. 30, 939-944. doi: 10.1086/605322

Paredes, C. J., Alsaker, K. V., and Papoutsakis, E. T. (2005). A comparative genomic view of clostridial sporulation and physiology. Nat. Rev. Microbiol. 3, 969-978. doi: $10.1038 /$ nrmicro 1288

Paredes-Sabja, D., and Sarker, M. R. (2011). Germination response of spores of the pathogenic bacterium Clostridium perfringens and Clostridium difficile to cultured human epithelial cells. Anaerobe 17, 78-84. doi: 10.1016/j.anaerobe.2011.02.001

Paredes-Sabja, D., Shen, A., and Sorg, J. A. (2014). Clostridium difficile spore biology: sporulation, germination, and spore structural proteins. Trends Microbiol. 22, 406-416. doi: 10.1016/j.tim.2014.04.003

Perez, J., Springthorpe, V. S., and Sattar, S. A. (2005). Activity of selected oxidizing microbicides against the spores of Clostridium difficile: relevance to environmental control. Am. J. Infect. Control 33, 320-325. doi: 10.1016/j.ajic.2005.04.240

Pizarro-Guajardo, M., Calderon-Romero, P., Castro-Cordova, P., Mora-Uribe, P., and Paredes-Sabja, D. (2016a). Ultrastructural variability of the exosporium layer of Clostridium difficile spores. Appl. Environ. Microbiol. 82, 2202-2209. doi: 10.1128/AEM.03410-15

Pizarro-Guajardo, M., Calderon-Romero, P., and Paredes-Sabja, D. (2016b). Revising the ultrastructure variability of the exosporium layer of Clostridium difficile spores from sporulating cultures and biofilms. Appl. Environ. Microbiol. 82, 5892-5898. doi: 10.1128/AEM.01463-16

Pizarro-Guajardo, M., Olguin-Araneda, V., Barra-Carrasco, J., Brito-Silva, C., Sarker, M. R., and Paredes-Sabja, D. (2014). Characterization of the collagenlike exosporium protein, BclA1, of Clostridium difficile spores. Anaerobe 25, 18-30. doi: 10.1016/j.anaerobe.2013.11.003

Riebe, O., Fischer, R. J., Wampler, D. A., Kurtz, D. M. Jr., and Bahl, H. (2009). Pathway for $\mathrm{H} 2 \mathrm{O} 2$ and $\mathrm{O} 2$ detoxification in Clostridium acetobutylicum. Microbiology 155(Pt 1), 16-24. doi: 10.1099/mic.0.022756-0

Rodriguez-Palacios, A., and Lejeune, J. T. (2011). Moist-heat resistance, spore aging, and superdormancy in Clostridium difficile. Appl. Environ. Microbiol. 77, 3085-3091. doi: 10.1128/AEM.01589-1510

Rupnik, M., Wilcox, M. H., and Gerding, D. N. (2009). Clostridium difficile infection: new developments in epidemiology and pathogenesis. Nat. Rev. Microbiol. 7, 526-536. doi: 10.1038/nrmicro2164

Russell, A. D. (1990). Bacterial spores and chemical sporicidal agents. Clin. Microbiol. Rev. 3, 99-119. doi: 10.1128/CMR.3.2.99

Schiott, T., and Hederstedt, L. (2000). Efficient spore synthesis in Bacillus subtilis depends on the CcdA protein. J. Bacteriol. 182, 2845-2854. doi: 10.1128/JB.182.10.2845-2854.2000

Setlow, P. (2006). Spores of Bacillus subtilis: their resistance to and killing by radiation, heat and chemicals. J. Appl. Microbiol. 101, 514-525. doi: 10.1111/j.1365-2672.2005.02736.x

Setlow, P. (2014). Spore resistance properties. Microbiol. Spectr. 2. doi: 10.1128/microbiolspec.TBS-0003-2012

Shen, A. (2012). Clostridium difficile toxins: mediators of inflammation. J. Innate Immun. 4, 149-158. doi: 10.1159/000332946

Slauch, J. M. (2011). How does the oxidative burst of macrophages kill bacteria? Still an open question. Mol. Microbiol. 80, 580-583. doi: 10.1111/j.13652958.2011.07612.x

Smits, W. K., Lyras, D., Lacy, D. B., Wilcox, M. H., and Kuijper, E. J. (2016). Clostridium difficile infection. Nat. Rev. Dis. Primers 2, 16020. doi: 10.1038/nrdp. 2016.20

Sorg, J. A., and Sonenshein, A. L. (2008). Bile salts and glycine as cogerminants for Clostridium difficile spores. J. Bacteriol. 190, 2505-2512. doi: 10.1128/JB. 01765-07

Stabler, R. A., He, M., Dawson, L., Martin, M., Valiente, E., Corton, C., et al. (2009). Comparative genome and phenotypic analysis of Clostridium difficile 027 strains provides insight into the evolution of a hypervirulent bacterium. Genome Biol. 10, R102. doi: 10.1186/gb-2009-10-9-r102

Steindl, G., Fiedler, A., Huhulescu, S., Wewalka, G., and Allerberger, F. (2015). Effect of airborne hydrogen peroxide on spores of Clostridium difficile. Wien. Klin. Wochenschr. 127, 421-426. doi: 10.1007/s00508-014-0682-6

Theriot, C. M., Bowman, A. A., and Young, V. B. (2016). Antibiotic-induced alterations of the gut microbiota alter secondary bile acid production and allow for Clostridium difficile spore germination and outgrowth in the large intestine. mSphere 1, e45-e15. doi: 10.1128/mSphere.00045-15

Theriot, C. M., and Young, V. B. (2015). Interactions between the gastrointestinal microbiome and Clostridium difficile. Annu. Rev. Microbiol. 69, 445-461. doi: 10.1146/annurev-micro-091014-104115

Thomas, C. M., and Smith, C. A. (1987). Incompatibility group P plasmids: genetics, evolution, and use in genetic manipulation. Annu. Rev. Microbiol. 41, 77-101. doi: 10.1146/annurev.mi.41.100187.000453

Tracy, B. P., Jones, S. W., and Papoutsakis, E. T. (2011). Inactivation of sigmaE and sigmaG in Clostridium acetobutylicum illuminates their roles in clostridial-cell-form biogenesis, granulose synthesis, solventogenesis, and spore morphogenesis. J. Bacteriol. 193, 1414-1426. doi: 10.1128/JB.01380-10

Vohra, P., and Poxton, I. R. (2011). Efficacy of decontaminants and disinfectants against Clostridium difficile. J. Med. Microbiol 60(Pt 8), 1218-1224. doi: 10.1099/jmm.0.030288-30280

Voth, D. E., and Ballard, J. D. (2005). Clostridium difficile toxins: mechanism of action and role in disease. Clin. Microbiol. Rev. 18, 247-263. doi: 10.1128/CMR.18.2.247-263.2005

Wilcox, M. H., Fawley, W. N., Wigglesworth, N., Parnell, P., Verity, P., and Freeman, J. (2003). Comparison of the effect of detergent versus hypochlorite cleaning on environmental contamination and incidence of Clostridium difficile infection. J. Hosp. Infect. 54, 109-114. doi: 10.1016/S0195-6701(02) 00400-0 
Wilson, K. H., Kennedy, M. J., and Fekety, F. R. (1982). Use of sodium taurocholate to enhance spore recovery on a medium selective for Clostridium difficile. J. Clin. Microbiol. 15, 443-446.

Conflict of Interest Statement: The authors declare that the research was conducted in the absence of any commercial or financial relationships that could be construed as a potential conflict of interest.
Copyright $\odot 2016$ Edwards, Karim, Pascual, Jowhar, Anderson and McBride. This is an open-access article distributed under the terms of the Creative Commons Attribution License (CC BY). The use, distribution or reproduction in other forums is permitted, provided the original author(s) or licensor are credited and that the original publication in this journal is cited, in accordance with accepted academic practice. No use, distribution or reproduction is permitted which does not comply with these terms. 